cerebral hemiatrophy. ${ }^{2}$ I believe that a factor distinguishing RE from hemconvulsion-hemiplegia-epilepsy (HHE) syndrome in our case was the timing of symptoms/imaging findings and the clinical course of our patient since that time. The progression of RE has been classically divided into 3 stages, with stage 1 (from onset of seizures and before development of hemiparesis) reported to have a mean duration of 2.8 years (range 3 months to 10 years). ${ }^{2}$ This is in contrast to our patient, who had onset of seizures and development of hemiparesis within 5 days or less. In addition, most patients with RE will have recurrent, medically refractory seizures while those with HHE syndrome will usually have a seizure free period (months to years) after the initial presentation before they might develop refractory seizures.

(C) 2012 American Academy of Neurology

1. Tenney JR, Schapiro MB. Child neurology: hemiconvulsion-hemiplegia-epilepsy syndrome. Neurology 2012;79: e1-e4.

2. Oguni H, Andermann F, Rasmussen T. The natural history of the syndrome of chronic encephalitis and epilepsy: a study of the MNHI series of forty-eight cases. In Anderman F, editor. Encephalitis and Epilepsy: Rasmussen's Syndrome. London: Butterworth-Heinemann; 1991: $7-35$.

\title{
CORRECTION
}

\section{Pearls \& Oy-sters: Ocular ischemic syndrome}

In the Resident \& Fellow article "Pearls \& Oy-sters: Ocular ischemic syndrome" by R. Fernandez-Torron et al. (Neurology ${ }^{\circledR}$ 2012;79:e92-e94), there is an error in the text. Duplex carotid ultrasonography revealed occlusion of the initial portion of the right internal carotid artery (as shown in figure 2), not the right common carotid artery. The authors regret the error. 


\section{Neurology}

\section{Pearls \& Oy-sters: Ocular ischemic syndrome \\ Neurology 2012;79;2368 \\ DOI 10.1212/WNL.0b013e318277b21c}

This information is current as of December 10, 2012

\section{Updated Information \&} Services

Permissions \& Licensing

\section{Reprints}

including high resolution figures, can be found at: http://n.neurology.org/content/79/24/2368.full

Information about reproducing this article in parts (figures,tables) or in its entirety can be found online at:

http://www.neurology.org/about/about_the_journal\#permissions

Information about ordering reprints can be found online:

http://n.neurology.org/subscribers/advertise

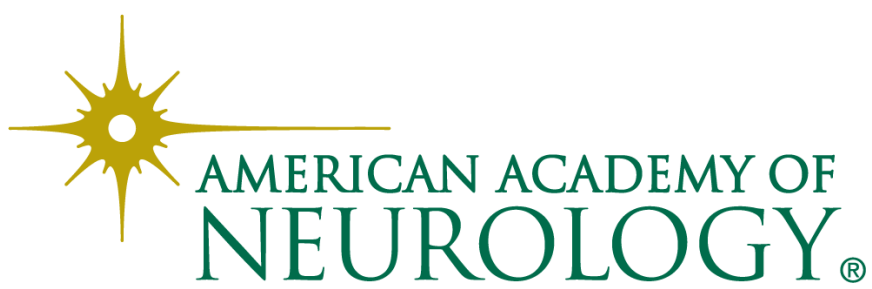

